\title{
The Death of Communism and the New World Order
}

\author{
Richard Greeman
}

Since the fall of the Berlin Wall in 1989, the ideologues of the Right have been congratulating themselves on the death of so-called Communism and proclaiming the everlasting triumph of neo-liberal free-market capitalism as the happy "End of History." However, the collapse of the "Evil Empire" came as a total surprise to these very Cold Warriors, who insisted on seeing Gorbachev's radical and irreversible moves as mere feints designed to throw the West off guard. For example, George Will was still writing "Liberalization is a Ploy" on the very day the Berlin Wall came down! As a result, the U.S. security establishment blew the chance to ally with Gorbachev when he still controlled the Soviet Union and could prevent the proliferation of unstable new nuclear states (certainly one of the greatest diplomatic blunders in modern history). Today, the same ideologues and "intelligence" experts are trumpeting the death of Marxism and the millennial triumph of a new capitalist World Order. However, the nature of what died in the East and what is struggling to be born is far from clear, and their new prognostications may prove just as illusory.

Western experts and Sovietologists had long been unanimous that Russia's closed totalitarian system was impervious to change from within, and could only be contained from without by military means. On the other hand serious independent Marxists like Leon Trotsky and Victor Serge, who understood the inner weakness of the Stalinist bureaucratic regime and the deep resistance of the workers, accurately foresaw today's transformations a half century ago. As early as 1936, they foresaw the trend toward privatization, and Serge spoke specifically about the dangers of revived nationalism and Islamic fundamentalism. ${ }^{1}$ So much for the idea that the collapse of Stalinism has "disproved" the validity of Marxism!

As Serge wrote just before his death in 1947:

\begin{abstract}
A poor excuse for logic, pointing an accusing finger at the dark spectacle of Stalinist Russia, asserts the failure of bolshevism, and therefore of Marxism and even socialism.... A facile attempt to conjure away the many problems gripping the world and which won't go away in the foreseeable future. Aren't you forgetting other failures? What was Christianity doing during the [recent] social catastrophes? What happened to liberalism? What was the end result of conservatism, whether reactionary or enlightened? Did it not give us Mussolini, Hitler, Salazar and Franco? If it were a question of honestly weighing the many failures of different ideologies, we would have our work cut out for us for a long time. And nothing is over yet. ${ }^{2}$
\end{abstract}

Serge died believing that it was reasonable to hope that the Russian people would eventually overthrow totalitarian Communism and move in the direction of democracy and a humanistic form of socialism.

1 See Trotsky's The Revolution Betrayed (New York 1972 [1937]) and Serge's Russia Twenty Years After (New York 1937), 286, especially his new 1947 Preface, "Russia Thirty Years After."

2 This quotation is from a posthumous manuscript entitled "Thirty Years After the Russian Revolution," ["Trente ans apres la revolution russe"] and dated July-August 1947, a few months before his death. It was first published as a "Postface" in "Tome III" of the 1971 Maspero Edition of Serge's L'An I de la revolution russe, 75-89. 
However the Revolutions of 1989, while they did revive the democratic and socialist hopes of the East European anti-Communist revolts of 1953, 1956, 1968, and 1981, did not fulfil them. These early, ill-fated freedom struggles all bore the same revolutionary stamp of mass self-activity - from the 1953 Berlin workers' uprising following the death of Stalin, through the 1956 Hungarian Revolution with its Workers' Councils. to the "socialism with a human face" of the Prague Spring of 1968 , and the original Polish Solidarity movement of 1981 . Their more or less explicit aim was democratic workers' control of society, that is to say socialism. Yet when the incubus of totalitarian Communism was finally lifted, what happened?

Far from fulfilling the early expectations of freedom, democracy, revival and reform, the Revolutions of 1989 ushered in a dismal period of passivity, demoralization, political stagnation, and economic chaos, of hardships, shortages, and unemployment; of narrow nationalism, internecine warfare, and authoritarian rule. Indeed, as East Europe and the ex-Soviet lands slide deeper into this morass, the only "light" at the end of the tunnel is apparently the dim possibility of the restoration of capitalism! And what kind of capitalism? Not the growth of small business, but an MMF-dictated bitter pill of austerity that can only lead to Latin-American-style dictatorship, debt and dependency! In fact, the fresh-minted "democrats" around Yeltsin openly declare that a "Pinochet-type solution" might be desirable if the masses, whose sufferings get worse daily (and for cause) fail to support what are euphemistically called "reforms."

How do we account for this horrible retrogression on the day after a victorious movement for liberation? Is it possible to found any rational hope for a socialist-humanist reorganization of society in the wake of the collapse of "Communism?"

To answer these questions we must begin by stating that the "Communism" which collapsed in Russia and East Europe bore as much relationship to the liberating ideas of Karl Marx's Communist Manifesto as the Spanish Inquisition did to the ideals of Jesus' Sermon on the Mount. It was not communism, the theory and practice of human self-liberation, that collapsed in 1989 but Stalinism, a totalitarian system of bureaucratic class rule based on anti-working class terror and forced labor in the interest of the Party-State apparatus: the dominant privilgensia or nomenklatura.

It is history's bitterest irony that this bureaucratic totalitarian system first took root on the ruins of a genuine popular revolution, the Soviet Revolution of October 1917. The Russian Revolution turned sour when the expected world revolution failed to rescue the Soviets from poverty, isolation, backwardness, and continuous capitalist attacks. Eventually it degenerated into Stalin's bureaucratic tyranny. Yet the fact that its new rulers, while constructing a system resembling fascism, derived their privileges and power from state, not private property and continued to pay lip-service to a bastardized form of Marxism, has led to endless ideological confusion. However, the proof that the Stalinist bureaucracy's takeover was an anti-socialist Counter-revolution has been obvious since the 1930's, when Stalin literally exterminated all the Marxists and revolutionaries in Russia including every member of Lenin's 1917 Central Committee but himself!

The Stalinist bureaucracy's cynicism and brutality were as ferocious as its legitimacy was flimsy. It murdered millions. Yet Stalinist economic planning, however crude and coercive, succeeded in turning a backward Soviet Union into the world's second industrial power with such speed that by 1945 Red Army tanks were 
able to overwhelm the industrial juggernaut of Nazi Germany, and Russia went on to compete head to head with the wealthy United States in a forty-year arms race. Today it is fashionable to dismiss Russia's state-capitalist command economy (and hence all forms of socialism and economic planning) as inherently inefficient. So let us recall that Communist Russia was able to industrialize during the Great Depression, when Western economies were stagnating, and that as late as the 1960 's Khrushchev's threat to "bury" the West economically was considered credible. On the other hand, as Victor Serge predicted, the absence in Russia of the essential socialist elements of democratic participation and intellectual freedom in the long run undermined the advantages of economic planning. Under Brezhnev and his successors, efficiency declined to the point where glasnost and perestroika became necessities for the economic survival of the system.

What Marxists like Serge had anticipated - and what Western experts could not understand — was that Stalin's eventual heir (in the event Mikhail Gorbachev) would be obliged to initiate a profound revolution from above in order to solve two major sets of problems for the privileged bureaucracy he headed. The first was to end the economic and technological stagnation gripping the economy, raise productivity. and eliminate the system of police terror to the extent of making scientific progress and cultural life possible for the educated elites. The second was to somehow legitimize the scandalous illegal privileges of the bureaucracy whose rule was based on the fiction of administering socialized wealth in the interests of the "true owners," the working masses, who might one day wake up and demand an accounting.

In retrospect, Gorbachev's reforms, although apparently slow and hesitant, were astoundingly radical, as was already obvious to us in $1988 .{ }^{3}$ Gorbachev realized that in order to revive the Russian economy, he would have to call off the ruinous arms race, which was eating up a huge percentage of the gross national product, and create the conditions for normal trade and exchange with the capitalist West. This entailed sacrificing the East European empire Stalin had established as a buffer-zone at the end of World War II while convincing his own military-industrial complex and his security apparatus to go along with him. To understand how radical Gorbachev was, try to imagine a U.S. President in 1985 convincing the Joint Chiefs, the FBI and the CIA to end the Cold War in a similar manner (and survive assassination)!

Moreover, Gorbachev understood that in the computer age progress is dependent on the free flow of information, hence of ideas, and he began to take the clamps off of free expression through glasnost, much to the dismay of the Party ideologues and conservative KGB types. As a counterweight to the die-hard Stalinists and Cold Warriors on his right, Gorbachev opened up some space for democratic forces; but he understood that if democracy went too far he might very well need his old colleagues in the Party and the KGB, and he did not want to alienate them - hence his constant vacillation. This hesitancy was most evident where his last reform, the famous perestroika or economic restructuring, was concerned. Although Gorbachev's advisors had their 600-day plans (and Yeltsin's their 500-days) little was known about them and even less done. Why?

3 See my pamphlet The Return of the Social Revolution, part of which appeared in New Politics Vol II No. 2 (Winter 1989) under the title, "Reflections on 1968 and Beyond." 
For the simple reason that the bureaucracy was not then and is still not ready to take on the masses of working people in an open and decisive contest over who will ultimately own and profit from the economy, that is to say who will inherit the social wealth built up at great suffering by the Soviet people over generations during which these same bureaucrats (or their predecessors) told the workers to sacrifice in order to "build socialism" for their children. Hence today's slow process of stagnation and decay, insecurity and price rises, all designed to demoralize the workers to the point that they will accept anything - even the IMF-Pinochet solution - in the name of reform, just to get things working again. Hence the encouragement of nationalism, even anti-Semitism, in order to divert attention from a potentially decisive class confrontation.

For what independent Marxists like Trotsky and Serge understood about the dynamics of the Stalinist system a half-century ago is still valid today. They believed that the ruling bureaucracy would be overthrown by the workers themselves within a generation or so, if there were no Second World War. But if the Stalinist system survived, these Marxists foresaw that the bureaucrats would inevitably attempt to integrate themselves into the world capitalist system and to turn their illegal privileges (ostensibly rewards for leading the workers to the promised land of socialism) into some kind of legal property. Trotsky saw this in terms of direct capitalist restoration; Serge through a process of joint-capital exploitation involving the West. Both were right. For the creation of this kind of Market Stalinism is, in essence, the program of the ex-Stalinist bureaucrats, freshly reborn as "democrats, "nationalists," and "freemarketeers," who have seized power in the ex-Soviet Union.

The process has been nicknamed "nomenklatura privatization" and it may be conceived as a kind of revolution-in-place. Ideally, the ex-Communist bosses would simply change hats, while remaining at their desks and in possession of the stateowned cars they drive, the state-owned mansions they live in, and the state-owned enterprises they manage. Only now the bureaucrats will be owners, not just "servants" of the "true owners," the socialist workers. Thus "Commissars" would become "Capitalists," "Comrade Managers" would become "Chief Executive Officers," and the old Soviet Privilgensia would become the principal stockholders and directors of the social capital they formerly administered. And since the "public sector" represents the whole national capital, even our multi-billion-dollar S \& L and banking swindles would pale in comparison with this massive theft of social wealth by a gang of inside traders.

However, the would-be bourgeois have problems. The first is the fear the workers won't let them get away with plundering the country. The bureaucrats have not forgotten the massive miners' strikes of 1989 and the amazing speed and boldness with which local, regional, and national strike committees were formed - committees which moved immediately from pure economic demands to political demands. So while the self-proclaimed democrats in power pal around with Chicago-school economists and talk endlessly of "reforms," they haven't yet dared implement their full program of austerity and privatization out of fear of a massive reaction from below.

However, their "low intensity" attack on the rights and living standards of working people is demoralizing enough. Planned massive price rises have reduced everyone but the privileged to desperation. Salaries are next to worthless. Pensions are simply 
not paid on the grounds of a manufactured "shortage" of money, while "before our eyes, our systems of free medical care and free universal education are being dismantled without our permission. with no legal basis." IMF-imposed conditions for loans may give the bureaucracy a cover for attacks on the living standards of the people, but they also expose the fact that the bureaucrats want to sell the Soviet Union out to foreigners. (Thus there is an economic as well as a demagogic basis for the alliance of right-wing nationalists and Stalinist dinosaurs in opposition to "reforms").

Parenthetically, let no one imagine that what the Yeltsin gang calls "free markets" has anything to do with the creation of small businesses and the development of capital through individual or cooperative labor. The principal successful examples of this type of capital formation are in the illegal private sector: an alarming growth of criminal mafias, swindlers and black marketeers. Bureaucratic restrictions, galloping inflation, and exorbitant new taxes continue to inhibit the actual creation of legitimate capitalist enterprises, so that even private farming, now technically legal, cannot take root - despite the ready market for produce. The "market Stalinists" who now hold power are incapable of creating new private wealth and have only one plan: to expropriate the existing public wealth through "nomenklatura privatizations" and sell-offs of natural resources similar to those of the Reagan-Bush looting decade. For example the Mayor of Moscow recently transferred the assets of a large municipal enterprise to a new private company in which he is the principal stockholder.

Meanwhile the ex-Soviet Union is going to hell in a handcart and no one - East or West - is doing anything about it. Although the violent "ethnic" quarrels in the Caucasus, the Crimea, and the Baltic have not yet reached the stage of ex-Yugoslavia, all the elements are present plus an additional wild-card - nuclear weapons. Let us note that two significant factors in all this "ethnic" violence have nothing to do with ethnicity. First, most of these conflicts are engineered by ex-Communist bureaucrats whipping up nationalist fervour in order to retain or expand their dictatorial power (and to make people forget their "internationalist" Stalinist pasts). Second, the exacerbation of national quarrels serves as a diversion from the need to solve social problems, raise living standards, establish practical democracy. As with the black on black "tribal" violence in South Africa, much of the "ethnic" violence in the ex-Soviet Union is provoked by the secret police in order to preserve minority rule - here that of the nomenklatura - and to prevent the working people from discovering and uniting around their common interests.

Meanwhile, on the economic front, all over the ex-Soviet Union farms stagnate and factories cease production for lack of parts, yet Yeltsin's advisors, like Gorbachev's before him, have no practical plans for reviving the resource-rich Russian economy nor any intention of encouraging initiatives from below, be they collective or actual free enterprise. Of course the privileged and powerful are not hurting like the common people who have seen the buying power of their salaries and pensions decline at a vertiginous rate. The nomenklatura are quietly looting retail while waiting until the day when they can loot wholesale. Perhaps they feel that shortages and nationalist squabbles will create enough demoralizing diversions that the long suffering Soviet peoples will eventually despair and willingly swallow the bitter pills of

4 Nikolai Preobrazhensky of the Petersburg Party of Labor, quoted in Bulletin, U.S. Soviet Workers Information Committee, Vol. 1 No. 2, Nov. 1992, 36. 
mass unemployment, homelessness, and the loss of health care and the social safety net in the name of "austerity."

On the other hand, the Soviet masses have suffered and labored, often heroically, for generations under totalitarian Communist bureaucrats who forced them to sacrifice in the name of "socialism." It is hardly reasonable to expect these same masses to sacrifice for another generation in order to enrich a few capitalists (in most cases the same bureaucrats) so that eventually the new wealth will "trickle down" to them. Yet this is precisely the "reform" Yeltsin's advisors are telling them they must accept! Hence, for the moment, we have stasis - which the Greeks understood as a violent and degenerative paralysis of a polity in the middle of an unfinished class war.

This stasis is further aggravated by unresolved antagonisms among sections of the nomenklatura itself, for the prospective bureaucratic bourgeois have already split into factions in anticipation of a division of the expected spoils. ${ }^{5}$ The historic August 16, 1991 "attempted right-wing coup" was little more than such a faction-fight played out in the streets, according to Boris Kagarlitsky, a leading spokesperson for the new Party of Labor and a socialist member of the Moscow City Council. ${ }^{6}$ Kagarlitsky describes the "coup" as an elaborate charade, staged with unarmed tanks and unloaded rifles, during which the Yeltsin people double-crossed the coup-makers and used the media to outfox the Gorbachev crowd in the generalized scramble for power. As a result of this spectacular political manoeuvre, the Soviet Union, Gorby's stronghold, was dissolved to the advantage of Yeltsin's Russia. At the same time, the big provincial Party apparatchiks like Ukraine's Kravchuk, originally sent by allpowerful Moscow to be dictators over captive "Republics," suddenly converted to "nationalism" in order to hold onto their local fiefdoms.

Within Russia, in the wake of the failed August coup, there was a great scramble to jump to the winning side. Every ex-Party boss from the Communist reformers around Gorbachev, through Yeltsin's "democrats" to various groups including neoStalinist and anti-Semitic nationalists (not excluding some of the coup-makers themselves) was born again as a free-marketeer. Yet within a year this unity of opportunists had fallen apart, as the representatives of the interests of the new entrepreneurs and those of the existing factory managers came to parliamentary blows over which privileged group should benefit most from privatization. In this struggle for spoils, the factory managers have the advantage of being able mobilize "their" workers against "outside" exploiters by manipulating the existing unions and work collectives. Naturally, independent organizations of working people are anathema to both power-groups.

Yet Kagarlitsky is certainly right that if there was a coup, it was Yeltsin who pulled it off. For "Czar Boris" immediately used the victory of "democracy" to vastly reinforce his own executive power to the detriment of actual democratic formations.

5 This spilt within the Stalinist ruling order was analyzed thirty years ago by two young Polish Marxists, Jacek Kuron and Karol Modzelwski, in an "Open Letter" to the Polish Workers (Communist) Party that landed them in jail. Their brilliant analysis of the bureacratic ruling class and the antagonism within it between the "central political bureaucracy" and the managers in the field was prophetic even if Kuron's subsequent political incarnation as an austerity Labor Minister provides an ironic commentary on the prophetic ideas of his heroic youth. A Revolutionary Socialist Manifesto (Open Letter to the Party) (London 1965).

6 See Boris Kagarlitsky "Yeltsin's Successful Coup" New Politics Vol. III, No. IV (New Series), $27 \mathrm{ff}$. 
Although Yeltsin called on the workers to strike and support him during the August charade and pledged that he would "lie on the railroad tracks" if his reforms were accompanied by price increases, he has in fact attacked workers' living standards while clamping down on the unions, both old and new. Among Yeltsin's first decrees was the banning of employee organization at the workplace (under the pretext of banning the Communist Party). The "democrats" in power are also clamping down on grass-roots organizations and parties like Kagarlitsky's Party of Labor, but the popularity of these new groupings, although limited, seems to be growing. What are the perspectives for a socialist revival in the ex-Soviet lands?

Fifty years ago, Leon Trotsky died believing that despite Stalin's perversion of socialism, the basis of collective property and collective labor had been so firmly established in the Soviet Union that a "political revolution," merely by sweeping away Stalin and his cronies, would be sufficient to restore socialism. Whether his analysis was correct at the time is moot, for the political revolution has arrived, a half-century too late, and it is now obvious that it will take a bitter class struggle, perhaps a civil war, before the working people of the ex-Union can expropriate their bureaucratic-bourgeois oppressors.

Moreover, such is the popular revulsion against the official Communism that justified so much suffering for so long, that, as Victor Serge predicted in 1947, it may be a long while before the mass of workers will be willing to listen to Marxist or socialist ideas. At the same time, the peoples of the ex-Soviet Union have so little experience with actually existing capitalism and have so many illusions about the consumer societies they imagine exist in the West, that they have no idea that their capitalist future will look more like Peru than like Switzerland. Although this would be tragic, some observers believe that the Soviet people will have to go through the actual experience of private capitalist exploitation before they are ready to overthrow it.

I, for one, am less pessimistic, and I hope for sound historical reasons.

Let us return again to our original question: Why did the Revolutions of 1989, instead of marking a new beginning for humanity and fulfilling the libertarian socialist aspirations of earlier anti-Communist revolts, open the road to the most serious retrogression, including economic and political stagnation, a failure to develop the basis of democracy in a renewed civil society, a revival of bloody internecine religious and national struggles, and the apparent triumph of neo-liberal Reaganomics in the East?

We have just explored the inner dynamics of the collapsing Stalinist empire, but for me, an essential part of the answer lies in examining the unfavourable international environment and historical context. In order to understand the importance of this context of world-wide recession and rampant Reaganism, let us exercise our fancies and imagine it otherwise. Let us imagine, for example, that Russian "Communism" had collapsed at the time of the world-wide revolutionary upsurges of 1968, rather than stagnating on for another twenty years.

Imagine that in 1968 instead of the Russian tanks invading Prague, the spirit of Prague Spring (which did in fact spark sympathy movements in Poland and demonstrations in the Soviet Union) had invaded Russia. Imagine that the masses of students and workers in rebellion in France and Western Europe against both capitalism and "Obsolete Communism" had poured across the Berlin Wall, not with the 1989 
message of consumerism and contempt, but burning with the holy 1968 freedom-fire and bringing with them the kind of practical solidarity that people with mimeograph machines and experience in political parties and trade unions can effectively share with new movements just getting organized. Imagine a United States paralysed by ghetto riots, anti-war demonstrations, and the collapse of adult authority. And while we're at it, why not imagine a self-organized workers' movement à la 1981 Polish Solidarity linking up with the wild-cat strike movements inflaming France, Italy, Britain and parts of the U.S., while the revolutions in Vietnam, Iran and Nicaragua keep the forces of imperialism off balance?

All of the above events did happen, albeit not simultaneously. However, there is nothing intrinsically impossible about our imaginary scenario, which certainly would logically have led to a genuine new world order based on spontaneous mass democracy and respect for human rights. What happened in fact, as we argued in our study of the sixties,' is that capitalism, after getting a good scare in 1968, counter-attacked and developed new techniques for suppressing rebellion and raising profits-culminating in the recent decade of transnational high-finance looting, reactionary social policy, and militarism.

However, the purpose of our imaginary exercise in the almost possible is not to argue that Communism collapsed 10 or 20 years too late for anyone's good, although that might turn out to be the case. It is rather to remind ourselves that the Revolutions of 1989 had the misfortune of taking place at the end of a decade of Reagan-BushThatcherite neo-capitalist retrogression, during a period of high unemployment and economic stagnation, and that the political environment was not exactly supportive to socialism and democracy. For example, the unfortunate East German democrats, who toppled the vicious Honecker regime with demonstrations sparked by their little civic clubs, hardly had a chance to breathe before Helmut Kohl came barrelling over the Wall with his Deutschmarks and his referenda and his plant-closings and privatizations. Nor did the sick, senile, cynical socialism of Mitterrand provide a shining example of solidarity for France's East European neighbours. Given this context of triumphant neo-liberalism, it was hardly reasonable to expect the poor Russians dragging themselves out of the radioactive mud of Chernobyl after 70 years of privation and brainwashing to come up with the clarity of mind to reject consumerism and espouse humanistic socialism without outside support.

However, there is nothing fated about this situation, and it could change quite rapidly. The "boom" of the eighties, which was not a boom in terms of working peoples' living standards, now appears to have paved the way for a bust. The false prosperity of U.S. military Keynesianism seems to have reached its limit, and even Japanese capital has contracted dramatically. Despite the help of banking deregulation and massive bailouts, the capitalists can't play poker endlessly on borrowed money - sooner or later the hands will be called, and then it's pay up or fold. The political and social bankruptcy of neo-liberal capitalism is already evident in race riots, unemployment, homelessness, human rights abuses and growing economic inequality. Its financial insolvency can't be concealed indefinitely. Meanwhile, there have been encouraging signs of a revival of worker militancy in Britain and Italy. 
To be sure, the death of so-called "Communism" left one and only one superpower, which, following its preordained victory in the Iraqi "turkey-shoot" proclaimed itself the leader of a "New World Order." However, the emptiness of that phrase was quickly revealed. Within a year it was obvious that under U.S. hegemony, not world order but worldwide violence and disorder still reign - and not only in the former Second and Third Worlds, but increasingly in the First. As in the 1930's, the Western democracies are standing aside while genocide is practiced in the heart of Europe (Bosnia). Meanwhile, Kohl's Germany retrogressed to tacitly encouraging neo-Nazism, Mitterrand's France refused to disavow the crimes of Vichy, and in the U.S., the Los Angeles revolt exposed both the racism of American society and the anger and despair of its under-privileged.

"New World Order" notwithstanding, Bush's tin-horn victories over his former henchmen, General Noriega and Saddam Hussein, solved none of the problems that allegedly provoked those two ghastly U.S. invasions. As Panama sinks deeper into dictatorship, drugs and money-laundering, the intact Hussein dictatorship rearms, renews its armed attacks on the Kurds, Shiites and democrats, and remains a formidable regional power. If anything, Bush's paltry triumphs demonstrate the sickness and ineptitude of the Western policy of selling arms to all comers and of propping up corrupt tyrants with secret supplies of cash and weapons in order to "tilt" against other perceived enemies.

Thus, Bush was afraid to campaign on his incomplete Gulf "victory" for fear of watching his fabricated pro-war consensus unravel in a new "Iraq-Gate" of illegal deals with Saddy-the-Baddy. Indeed, even during the jingoistic media blitz against the mind of the U.S. public that was arguably Bush's greatest Desert Storm victory, his support was so thin that both of the two anti-Gulf War demonstrations in Washington (organized on successive weekends in January 1991 by the usual squabbling rival Leftist coalitions) attracted more actual participants than Bush's ballyhooed multi-million-dollar Victory Celebration in the Spring. The subsequent electoral defeat of the architect of the "New World Order" revealed both the superficiality of "manufactured consent" and the depth of the economic crisis.

Meanwhile, right in the U.S.'s backyard, the revolutionary and popular movements in the tiny countries of Nicaragua and El Salvador remain undefeated and have forced the U.S.-backed right-wing governments into uneasy stand-offs. One recalls that the destruction of the revolutionary movements in Nicaragua and El Salvador was at the top of the foreign policy agenda of the Reagan-Bush New Right when it took office in 1980. The survival of these two minuscule nationalist-revolutionary movements after twelve years of massive U.S.-orchestrated repression (and especially after their abandonment by their Russian allies) represents a clear defeat for the New World Order.

In El Salvador, the guerillas of the FMLN succeeded in fighting the right-wing army to a stand-off, despite billions of dollars in U.S. military aid. The U.N. supervised truce can help open some political space for the teachers, trade-unionists, peasants, Catholic human rights workers and left politicians to organize against the Salvadoran death-squad oligarchy. At the same time, tiny Nicaragua continues to stand defiant against U.S. imperialism even after the electoral victory of the conservative Violetta Chamorro over the revolutionary Sandinistas. In spite of the painful setbacks in health and education following Violetta's election, her bourgeois govern- 
ment refuses to concede to U.S. pressures on questions of sovereignty, and she maintains the Sandinista Army and Police intact in order to keep the CIA-backed Contras at bay and to defend the national interest. ${ }^{8}$

These are small and ambiguous victories to be sure. But they are signs that U.S. hegemony is vulnerable to an international revival of social struggles around issues of sovereignty, human rights, land reform, the environment, and decent conditions of life and labour. And the U.S. solidarity movement as well as the generalized public revulsion against Vietnam-type adventures deserve part of the credit for the success of this resistance.

Back in Russia, moreover, despite the apparent hegemony of IMF-Yeltsin "free market Stalinism", the ultimate battle between the bureaucrats and the workers for control of the economy has yet to be decided. The "backward" Soviet people still reject the profit system as immoral if not illegal, and the true spirit of communism may yet take its revenge on the fat-cat ex-Communist bosses who hypocritically preached it only yesterday. Moreover, there are promising developments like new movements among the Russian trade unions, regional and national strike committees, the potential radicalization of workers' self-management collectives in the old state enterprises, and the recent foundation of the Party of Labor, based on these movements, which may take root if political freedom is maintained.

If ever there was a time to think and act globally, it is now. The Cold War bogeyman is no longer there to frighten people into numbed paralysis. No longer can "anti-Communism" be used to suppress U.S. popular movements, as it was against generations of labor organizations and civil rights groups, from the Wobblies to Martin Luther King. Conversely, Communist agents and parties can no longer be used to divert popular mass movements into pro-Russian channels or to betray them as the Stalinists did in Spain in 1936 and in France in 1968. Nor can ex-Party bosses like Yeltsin any longer use the excuse of "aiding the capitalists" to suppress the champions of labour and human rights in Russia. However bleak the post-1989 scene may be in appearance, the historical reality is that an incubus has been lifted that was sapping the life-blood of the revolutionary movement.

Indeed, whatever may have kept the revolts of 1953, 1956, and 1968 isolated from each other, today nothing keeps Western movements from uniting with their Eastern comrades except mutual misconceptions. These are many, and representatives of the U.S. labour bureaucracy, the CIA and State Department are busy directing disinformation campaigns at Russian workers to spread illusions. For example, anarcho-syndicalist militants I spoke with in Moscow had been told that the influence of union pension-plans made the U.S. some kind of worker-controlled peoples' capitalism. However, groups like "The U.S.-Soviet Workers Information Committee" have taken the initiative to solicit and publish materials on workers' and socialist struggles in

8 Precisely because Nicaragua has refused to become another Honduras or Guatemala, the Chamorro government is not receiving the promised U.S. aid that may have won her votes. Moreover, by submitting to the (momentary) will of the majority, the Sandinista's have set a unique precedent among vanguard parties and avoided creating yet another bureaucratic tyranny to besmirch the name of socialism. If the Sandinistas are able to deepen their links with the masses and hold onto their arms during this period of retreat into legal opposition, they may yet teach the world a new lesson if and when conditions become more favourable for revolutionary resurgence. 
Russia, to make materials about conditions and forms of struggle in the U.S. available there, and to organize discussions and exchanges. These efforts must be expanded.?

It is time to extend the kind of solidarity work that has proven both effective and mutually enriching in Latin America to the struggling peoples of Eurasia. Internationalism must be the order of the day, beginning with information exchange, direct contact and material aid to social movements struggling in the ex-Communist lands. Nor should North American wage earners allow phony patriotism, like the Japanbashing of Lee Iacocca and his labour lieutenants of the United Auto Workers International (sic!), to blind us to the fact that the transnational corporations are playing on national fears to create competition among workers, depress everyone's living standards, and degrade the environment world-wide. An injury to one is quite immediately an injury to all, for the cheapening of labour, whether in Salvador or in Siberia means lower wages in North America as surely as the radioactive fallout from Chernobyl affects the milk we drink.

With the end of the Cold War, a global solidarity movement to create a new, truly human world order becomes a practical possibility, and only such a global movement can effectively oppose the destruction of the world by globally-organized capital in its private or state form. One hundred-fifty years ago, when the industrial revolution was new, the rallying cry of the First International was "Working people of all countries unite, we have a world to win." Today, the capitalist system has exhausted all its progressive features and has nothing left to offer the world but the consumerist rat-race for the "lucky" few and the barbarism of endless wars and famines for the vast majority of humankind. As we enter the twenty-first Century we not only still have "a world to win," we also have a planet to lose.

9 For further information, contact the U.S.-Soviet Worker Information Committee, P.O. Box 1890, New York, New York 10009 and subscribe to its informative Bulletin quoted above. See also the newly-formed "Russian Democratic Left Support Group" (c/o Bowman, 26-3 Mt. Archer Red., Lyme CT 06731) and the Transnational Information Exchange, Paulus Potterstraat 20, 1071 DA Amsterdam, The Netherlands. Fax: 31-20-6757176. 